\title{
GEOMAGNETIC EFFECTS CAUSED BY ROCKET EXHAUST JETS
}

\author{
Yu.V. Lipko, A.Yu. Pashinin, R.A. Rakhmatulin, V.V. Khakhinov \\ Institute of Solar-Terrestrial Physics SB RAS, Irkutsk, Russia, \\ lipko@iszf.irk.ru,pash@iszf.irk.ru,rav@iszf.irk.ru,khakhin@iszf.irk.ru
}

In the space experiment Radar-Progress, we have made 33 series of measurements of geomagnetic variations during ignitions of engines of Progress cargo spacecraft in low Earth orbit. We used magneto-measuring complexes, installed at observatories of the Institute of Solar-Terrestrial Physics of Siberian Branch of the Russian Academy of Sciences, and magnetotelluric equipment of a mobile complex. We assumed that engine running can cause geomagnetic disturbances in field tubes crossed by the spacecraft. When analyzing experimental data, we took into account the following space weather factors: solar wind parameters, total daily mid-latitude geomagnetic activity index $K_{p}$, geomagnetic auroral electrojet index AE, global geomagnetic activity.

The empirical data we obtained indicate that 18 of the 33 series showed geomagnetic variations with various periods.

Keywords Active Radar-Progress space experiment - Geomagnetic pulsations - Geomagnetic field variations · Space weather

\section{INTRODUCTION}

At the dawn of the space era, many researchers drew attention to the possible influence of anthropogenic factors on Earth's atmosphere. The most efficient ways of active anthropogenic influence on geophysical process in Earth's atmosphere and magnetosphere are nuclear explosions, emissions of chemical compounds, and heating by electromagnetic radiation [Naumov et al., 2014].

Local geomagnetic disturbances of natural and anthropogenic origin became widely known after the first highaltitude nuclear explosions [Fatkullin, 1982]. The study of anthropogenic nuclear processes generating local geomagnetic disturbances suggests that launches of carrier rockets can also trigger a series of ionospheric processes able to cause peculiar geomagnetic variations [Smirnova et al., 1995].

When examining active effects on geophysical processes, many experiments have been carried out in artificial plasma formations in the ionosphere. Their evolution can favor the generation of electrojet currents, local current systems, and magnetohydrodynamic disturbances. Geophysical processes are also actively affected by emissions of chemical plasma-extinguishing substances, injection of electrojet currents into the ionosphere, and laser emission [Naumov et al., 2014]. 
Dmitriev et al. in [Dmitriev et al., 2002] conducted an experiment in monitoring of geomagnetic variations, which could occur after the launch of carrier rockets. The study has revealed that 8-18 hr after most launches of carrier rockets there was an abnormal decrease in geomagnetic strength (the full vector $T$ and the vertical $Z$ component). The intensity of the maximum decrease in geomagnetic strength varied from 20 to $200 \mathrm{nT}$. Gradient of the decrease ranged from 7 to $28 \mathrm{nT} / \mathrm{hr}$. The time of complete relaxation of the geomagnetic field also varied widely from $8 \mathrm{hr}$ to days and more [Dmitriev et al., 2002].

Our study of geomagnetic variations is part of the active space experiment Radar-Progress [Lebedev et al., 2008; Khakhinov et al., 2010; Khakhinov et al., 2012; Potekhin et al., 2009]. The space experiment was set up by the Federal State Unitary Enterprise Central Scientific Research Institute for Technology and Mechanical Engineering (TSNIIMASH). S.P. Korolev Rocket and Space Corporation «Energia» was responsible for the development of program-methodical software and technical implementation of the space experiment. The space experiment sessions used a ground-based spaced complex of radio, optoelectronic, magnetometric, and navigational equipment of the Institute of Solar-Terrestrial Physics of Siberian Branch of the Russian Academy of Sciences (ISTP SB RAS) and Progress cargo spacecraft (PCS) during the free-flight phase after accomplishing their main mission of delivering cargoes to the ISS.

When a PCS was in the field of view of the Irkutsk Incoherent Scatter Radar, at precomputed time intervals its onboard approach correction engine (ACE), which consumed $1 \mathrm{~kg}$ of fuel per second, was started and kept running for 8-10 s. High-energy exhaust jets might have generated electromagnetic disturbances in magnetosphereionosphere plasma, which might have been registered by the ground-based magnetometric equipment.

Therefore, at the ISTP SB RAS observatories and at the point of projection of geomagnetic field tube, at which the PCS was expected to be, on Earth's surface, induction magnetometers worked and geomagnetic variations were monitored in different time periods.

This work is aimed at examining possible magnetic disturbances occurring during the PCS's engine running.

\section{EXPERIMENTAL METHODS}

Coordinates of projections of geomagnetic field tubes, crossed by the PCS with running ACE, on Earth's surface were calculated from MCC (the Mission Control Center) data. Geographic coordinates were calculated using Tsyganenko’s DGRF/IGRF geomagnetic field model (http://omniweb.gsfc.nasa.gov/vitmo/cgm_vitmo.html).

The mobile complex for registration of geomagnetic variations was delivered to an observation point, which was the nearest to the calculated projection of the field tube, and was deployed there for continuous registration. The complex consists of a recorder LEMI-419, two high-sensitive induction sensors LEMI-120 (oriented north-south and east-west), a laptop, and storage batteries. LEMI-419 records magnetic variations in a frequency range 0.001$200 \mathrm{~Hz}$ with resolution of $0.01 \mathrm{nT}$. During filed observations, the complex was in a vehicle; the sensors were placed at a distance of $40 \mathrm{~m}$ from the complex to reduce noise. Due to the very high sensitivity to vibrations and wind noise, the sensors were put to special-purpose trenches $20-30 \mathrm{~cm}$ deep with materials for damping oscillations (sand) on the bottom. They were oriented by compass and spirit level. 
After having been installed, the sensors were covered by protective waterproof casings at the site where plugs were connected. The trenches were covered above to protect them from precipitation and wind.

The sensors were installed at least $1 \mathrm{hr}$ before recording to stabilize their temperature and reduce magnetic noise to the level of normalized noise.

Observers were placed in a camping site at no less than $50 \mathrm{~m}$ from the sensors. To exclude electromagnetic noises produced by a portable gasoline electric generator, the equipment was powered by storage batteries. A recording session was bounded by the laptop's battery life $-4 \mathrm{hr}$. Then, the storage batteries were charged by a generator to prepare the complex for the next session. To minimize anthropogenic electromagnetic noises, we placed the complex far from inhabited localities, roads, and power transmission lines.

Simultaneously with the mobile complex, magnetometric complexes of the ISTP SB RAS observatories Partony, Uzur, Mondy, and Norilsk were working. The first three stations were situated in the region where the space experiment was performed, i.e., near the projection of the PCS orbit on Earth's surface. The auroral observatory Norilsk was a reference station that monitored high-latitude disturbances, which can significantly contribute to the spectrum of observable mid-latitude oscillations [Lipko et al., 2001; Rakhmatulin, 2010, et al.].

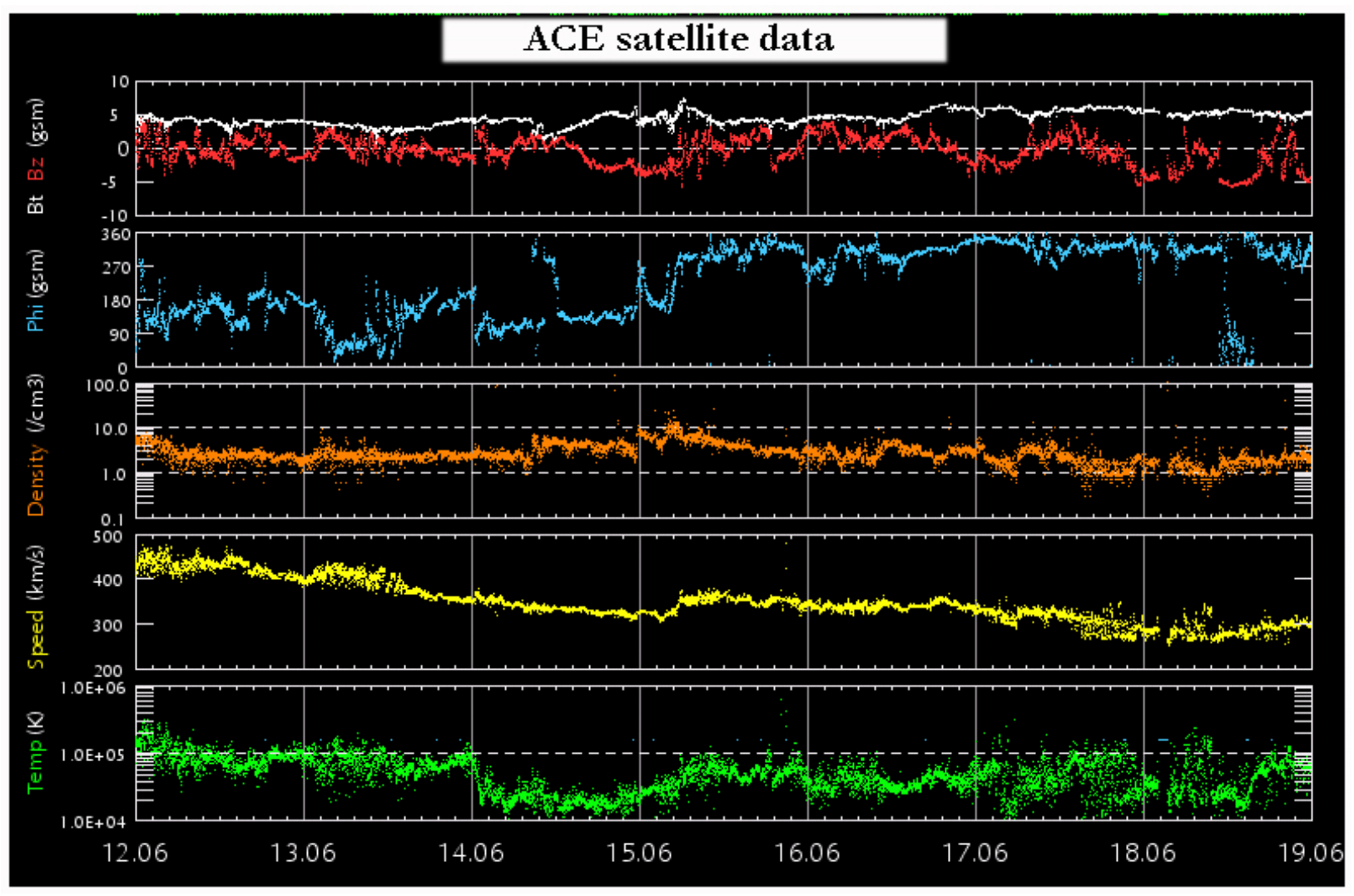

Figure 1. ACE satellite data for June 12-19, 2013 [http://www.swpc.noaa.gov/ftpmenu/lists/ace.html] 
After the field and observatory observations, we processed experimental results at central office. The fact that the spectral and amplitude regimes of geomagnetic pulsations at middle and high latitudes depend on ionospheric conditions [Rakhmatulin, Petrovsky, 1994; Lipko et al., 2001; Rakhmatulin, Pashinin, 2005] was necessarily taken into account in the analysis of recorded signals.

For each event, we examined solar wind conditions, estimated the level of magnetic disturbances on the global scale, magnetic conditions in the region of interest and in the auroral zone. All these measures were intended to exclude events during which geomagnetic effects from the PCS's engines were superimposed on natural geomagnetic variations.

The global level of magnetic disturbances was controlled using the magnetic indices $K_{\mathrm{p}}, A E, A L$, and $A U$.

The level of the geomagnetic conditions as a function of the $K_{\mathrm{p}}$ index can be roughly characterized as follows:

- $K_{\mathrm{p}}<=2$ indicates undisturbed geomagnetic conditions; $K_{\mathrm{p}}=2,3$, slightly disturbed; $K_{\mathrm{p}}=4$, disturbed;

- $K_{\mathrm{p}}=5,6$, magnetic storm; $K_{\mathrm{p}}>=7$, strong magnetic storm.

The level of magnetic disturbances at high latitudes is characterized by the auroral electrojet index $A E$. This index is calculated from magnetograms of $H$ components obtained at auroral or subauroral observatories, which are evenly distributed in longitude. At present, $A E$ indices are computed from data acquired at 12 observatories situated in the Northern Hemisphere at different longitudes between $60^{\circ}$ and $70^{\circ}$ geomagnetic latitude. Substorm activity is also numerically described by the geomagnetic indices $A L$ (the greatest negative magnetic variation) and $A U$ (the greatest positive magnetic variation).

Solar wind data were borrowed from [http://www.swpc.noaa.gov/ftpmenu/lists/ace.html]. Values of the $A_{\mathrm{p}}$ and $K_{\mathrm{p}}$ indices were taken from [http://ipg.geospace.ru/]. Variations in the $A E, A U, A L$ indices and data on magnetic conditions at auroral latitudes were imported from [http://wdc.kugi. kyoto-u.ac.jp/ae_provisional/index.html].

The regional level of magnetic disturbances was monitored using data from ISTP SB RAS magnetic observatories.

\section{EXPERIMENTS PERFORMED ON JUNE 13-18, 2013}

\section{Space weather conditions}

Space weather conditions for June 13-18, 2013 are illustrated in Figure 1. For the entire period, solar wind parameters were undisturbed. The solar wind velocity decreased gradually from $400 \mathrm{~km} / \mathrm{s}$ on June 12 to $260 \mathrm{~km} / \mathrm{s}$ by the midday of June 18 . The southern component of the interplanetary magnetic field fluctuated within $B_{\mathrm{z}}= \pm 5 \mathrm{nT}$. 


\section{Geomagnetic conditions}

Data on the $K_{\mathrm{p}}, A_{\mathrm{p}}$ indices characterizing geomagnetic conditions during the space experiment sessions are presented in Figure 2 and Table 1. Figure 2 shows that the experiment was carried out under very quiet conditions in the mid-latitude magnetosphere $\left(K_{\mathrm{p}} \sim 1-2\right)$.

Magnetic conditions at high latitudes were analyzed from the auroral indices (Figure 3).

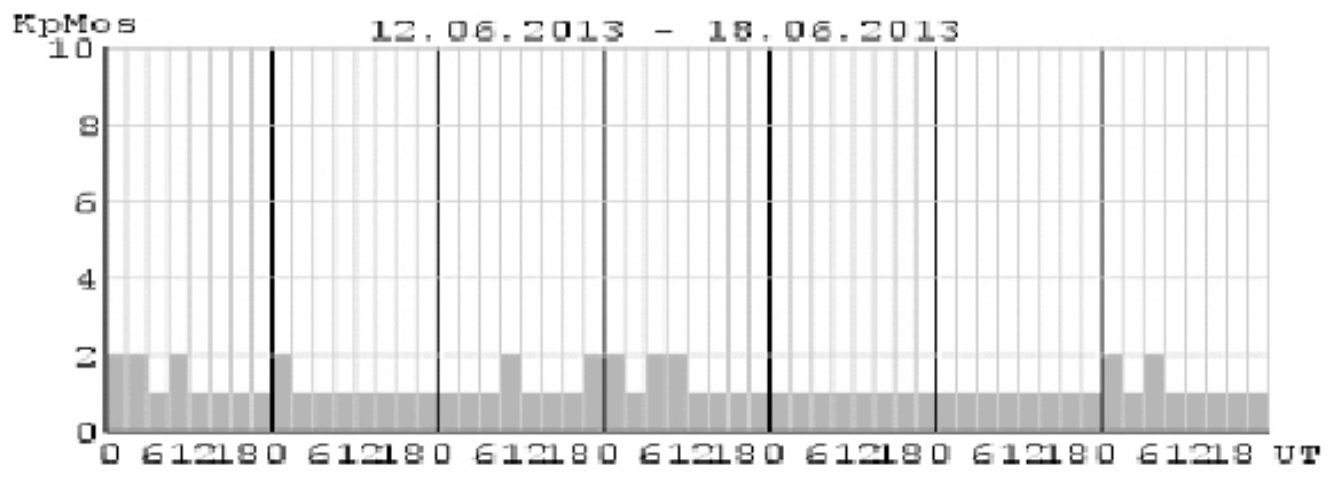

Figure 2. Values of the $K_{\mathrm{p}}$ index [http://ipg.geospace.ru/weekly-geomagnetic-forecast.html]

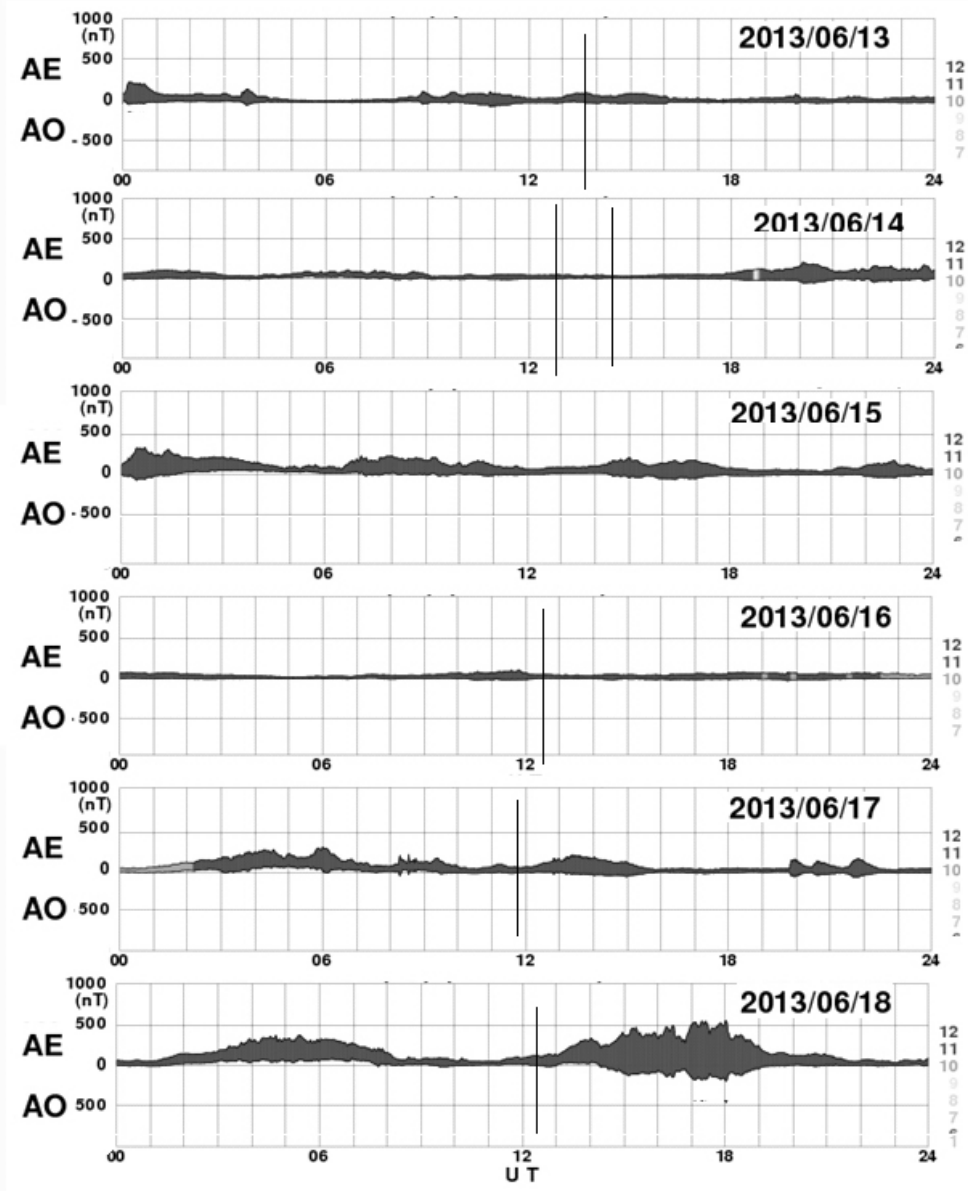

Figure 3. Values of the $A E$ index during the experiment. Vertical lines indicate periods of the PCS's ACE running 
Table 1

Geomagnetic field according to data from [http://ipg.geospace.ru/ weekly-geomagnetic-forecast.html]

\begin{tabular}{|c|c|c|}
\hline Data & $\begin{array}{c}\text { Conditions } \\
\text { (according to } A_{\mathrm{pMos}} \text { ) }\end{array}$ & $A_{\mathrm{pMos}}$ \\
\hline June 12,2013 & very quiet & 005 \\
\hline June 13,2013 & very quiet & 004 \\
\hline June 14,2013 & very quiet & 004 \\
\hline June 15,2013 & very quiet & 005 \\
\hline June 16,2013 & very quiet & 004 \\
\hline June 17,2013 & very quiet & 004 \\
\hline June 18,2013 & very quiet & 005 \\
\hline
\end{tabular}

Almost all the events developed in the absence of high-latitude disturbances. This is evident from data presented in Figure 3.

The experimental material was analyzed as follows. The reference point was the start of the PCS's ACE. Data from the induction magnetometers and the program SVAN (spectral and temporal analysis) were used to build the dynamic spectrum of oscillations for the periods when engines worked as well as $1 \mathrm{hr}$ before they were started and after they were cut off. The mobile complex was placed nearby the village of Yeloty $\left(52^{\circ} 55^{\prime} 35^{\prime \prime} \mathrm{N}, 102^{\circ} 14^{\prime} 23^{\prime \prime} \mathrm{E}\right)$. Measured data are shown in Figures 4-9.

June 13, 2013 (AE<20 nT, $K_{p}=1$; very quiet period)

After the PCS's engines started, there appeared pulsations with a period of $\sim 57 \mathrm{~s}$ under very quiet magnetic conditions, which recurred in 12 minutes (Figure 4).

June 14, 2013 (AE<20 nT, $K_{p}=1$; very quiet period)

During the first pass of the PCS after its engines were started there occurred $\sim 80 \mathrm{~s}$ geomagnetic variations (Figure 5).

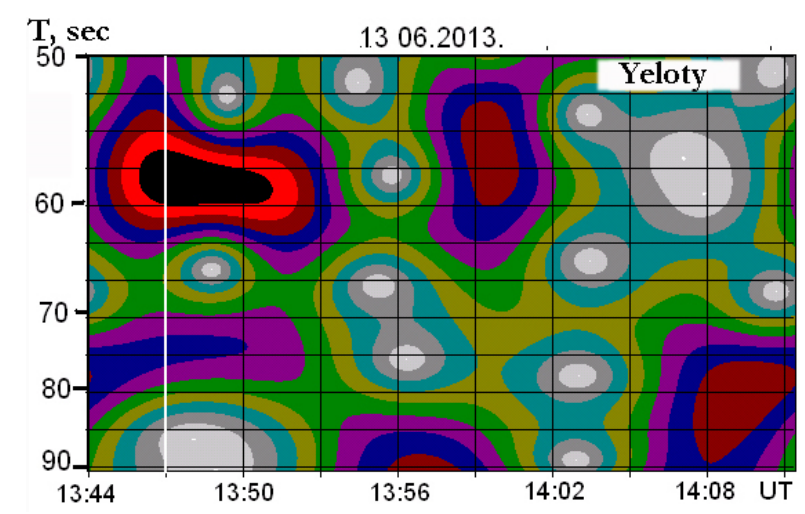

Figure 4. Dynamic spectrum of geomagnetic pulsations registered by LEMI-419 on June 13, 2013. The $H_{\mathrm{n}-\mathrm{s}}$ component (horizontal north-south). The vertical line indicates the instant of engine ignition 


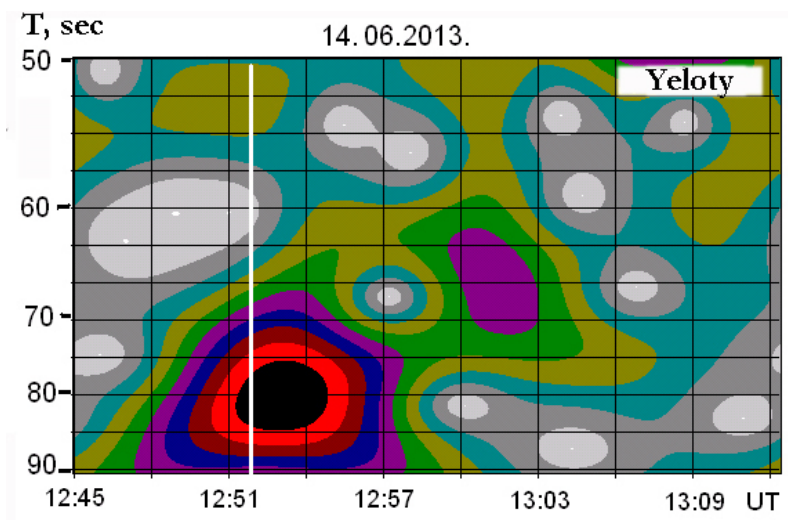

Figure 5. The same during the period of the first PCS pass on June 14, 2013

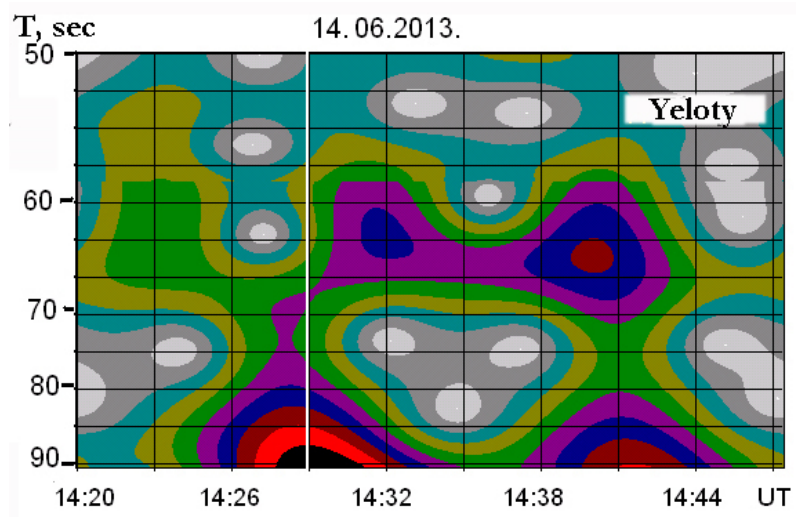

Figure 6. The same during the second pass on June 14, 2013

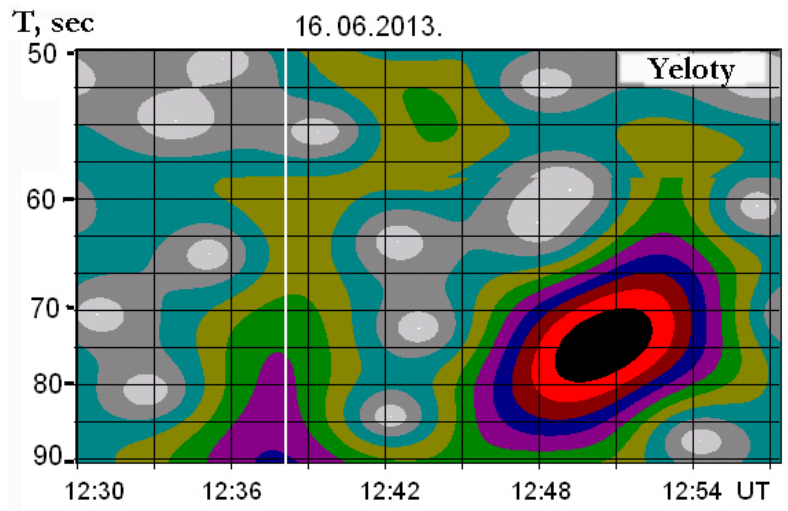

Figure 7. The same for June 16, 2013

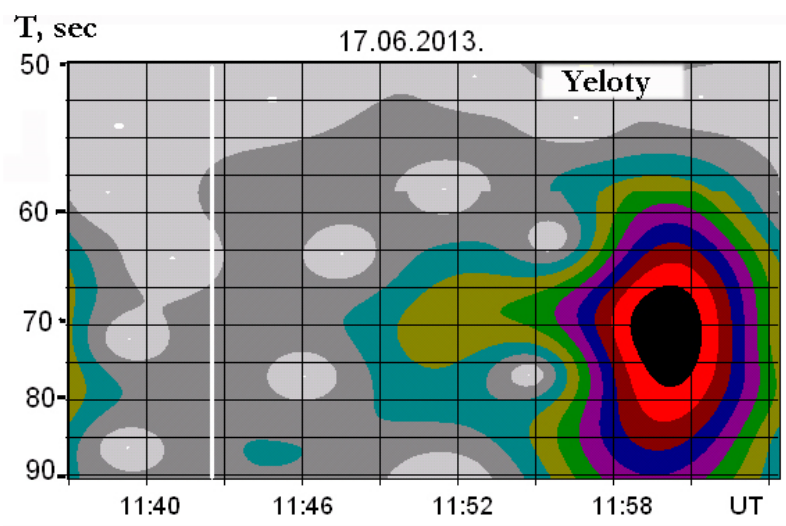

Figure 8. The same for June 17, 2013 


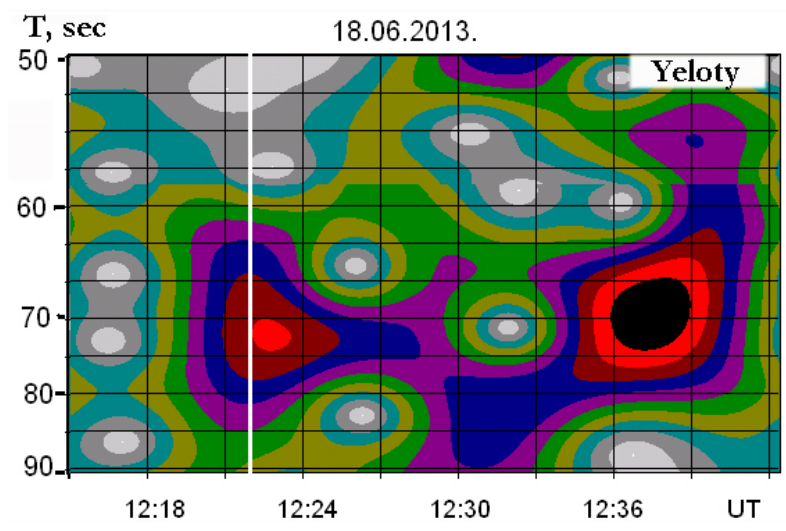

Figure 9. The same for June 18, 2013

During the second pass of the PCS after its engines were started, $\sim 65 \mathrm{~s}$ pulsations under very quiet magnetic conditions were registered. They recurred in 9 minutes (Figure 6).

June 16, 2013 ( $A E<20 n T, K_{p}=1$; very quiet period)

After the PCS's engines were started, $\sim 75 \mathrm{~s}$ pulsations under very quiet magnetic conditions were observed. They recurred in 10 minutes (Figure 7).

June 17, 2013 (AE<70 nT, $K_{p}=1$; quiet period)

After the engines were started, $\sim 65 \mathrm{~s}$ pulsations under quiet magnetic conditions were registered. They recurred in 15 minutes (Figure 8).

June 18, 2013 (AE 150 nT, $K_{p}=1$; slightly disturbed period)

Under weak geomagnetic disturbances there appeared $\sim 70 \mathrm{~s}$ pulsations, which recurred in 15 minutes (Figure 8).

Thus, virtually all the geomagnetic pulsations (with rare exception) during PCS passes in April and June 2013 occurred under very quiet and quiet geomagnetic conditions. The data analysis indicates that during the experiments conducted in 2013 long-period oscillations (25-150 s) often appeared after ACEs were cut off. To facilitate the analysis of all the events considered, we match instants of ACE start in Figure 10. The experimental results obtained in June 2013 were supplemented by some results received in April 2013 when the complex with recording equipment was installed in the ISTP SB RAS Observatory Tory $\left(51^{\circ} 48^{\prime} 38^{\prime \prime} \mathrm{N}, 103^{\circ} 4^{\prime} 38^{\prime \prime} \mathrm{E}\right)$.

All these events are characterized by generation of 25-160 s geomagnetic variations. In some cases, the signal recurred in 6-15 minutes. It must be emphasized once more that almost all the pulsations we registered occurred under very quiet and quiet geomagnetic conditions both in middle and high latitudes. This eliminates the risk of mixing up the observed effect and disturbances from other sources.

\section{CONCLUSION}

The Radar-Progress space experiments were aimed at registering variations in Earth's electromagnetic field in different frequency ranges during passes of PCS with running engines, with subsequent analysis of obtained data. 
We assumed that ACE work can generate geomagnetic disturbances in field tubes, crossed by PCS, in certain frequency ranges.

Under this program, we have carried out 33 series of measurements of geomagnetic variations during PCS passes over the ISTP SB RAS observatories and temporal observing points. The most complete information on the experiments is presented in Table 2.

This table shows that in 18 series (of 33) we could observe geomagnetic variations with various periods.

Series of measurements of auroral disturbances are distributed as follows:

- quiet background conditions - 10 series;

- at the onset of the disturbance -6 series;

- at the end of the disturbance -7 series;

- during the disturbance - 7 series;

- between disturbances -3 series.

Table 2

\begin{tabular}{|c|c|c|c|c|c|c|c|c|}
\hline $\begin{array}{l}\text { Session } \\
\text { number }\end{array}$ & Data & $\begin{array}{c}\text { Time of } \\
\text { ACE start }\end{array}$ & $\Sigma K_{\mathrm{p}}$ & $K_{\mathrm{p}}$ & $A E$ & $\begin{array}{c}\text { Magnetic } \\
\text { conditions } \\
\text { global }\end{array}$ & $\begin{array}{c}\text { Magnetic } \\
\text { conditions } \\
\text { auroral zone }\end{array}$ & $\begin{array}{l}\text { Excitation of } \\
\text { geomagnetic } \\
\text { oscillations }\end{array}$ \\
\hline 1 & $\begin{array}{l}\text { August } \\
23,2011\end{array}$ & 12:46:18 & 15 & 2 & $<20$ & very quiet & $\begin{array}{l}\text { quiet background } \\
\text { conditions }\end{array}$ & $T \sim 65 \mathrm{~s}$ \\
\hline 2 & $\begin{array}{l}\text { August } \\
29,2011\end{array}$ & $11: 21: 40$ & 14 & 3 & $<30$ & Substorm end & $\begin{array}{c}\text { end of } \\
\text { disturbances }\end{array}$ & $\begin{array}{l}\text { before and } \\
\text { after }\end{array}$ \\
\hline 3 & $\begin{array}{l}\text { April 23, } \\
2012\end{array}$ & 10:37:57 & 27 & 2 & 20 & weakly disturbed & $\begin{array}{l}\text { quiet background } \\
\text { conditions }\end{array}$ & None \\
\hline 4 & $\begin{array}{l}\text { April 24, } \\
2012\end{array}$ & 11:19:22 & 28 & 2 & 250 & weakly disturbed & during the disturbance & $\begin{array}{l}\text { before and } \\
\text { after }\end{array}$ \\
\hline 5 & $\begin{array}{l}\text { April 25, } \\
2012\end{array}$ & 10:23:55 & 26 & 3 & 600 & unstable & during the disturbance & $25-35 \mathrm{~s}$ \\
\hline 6 & $\begin{array}{l}\text { April 26, } \\
2012\end{array}$ & 09:27:51 & 21 & 2 & 20 & quiet & $\begin{array}{l}\text { after the disturbance } \\
\text { under quiet } \\
\text { background } \\
\text { conditions }\end{array}$ & $0.3 \mathrm{~s} ; 35 \mathrm{~s}$ \\
\hline 7 & $\begin{array}{l}\text { April 26, } \\
2012\end{array}$ & 11:04:06 & 21 & 2 & 150 & quiet & during the disturbance & $35 \mathrm{~s}$ \\
\hline 8 & $\begin{array}{l}\text { April 28, } \\
2012\end{array}$ & 09:10:03 & 20 & 2 & 80 & quiet & Disturbance onset & $\begin{array}{l}\text { equipment } \\
\text { failure }\end{array}$ \\
\hline 9 & $\begin{array}{l}\text { August } \\
15,2012\end{array}$ & $14: 26: 27$ & 13 & 2 & 20 & very quiet & $\begin{array}{l}\text { quiet background } \\
\text { conditions }\end{array}$ & $55-65 \mathrm{~s}$ \\
\hline 10 & $\begin{array}{c}16.08 .20 \\
12\end{array}$ & $13: 27: 16$ & 21 & 2 & 60 & quiet & Disturbance onset & $\begin{array}{l}\text { before and } \\
\text { after }\end{array}$ \\
\hline
\end{tabular}




\begin{tabular}{|c|c|c|c|c|c|c|c|c|}
\hline 11 & $\begin{array}{c}\text { April 17, } \\
2013\end{array}$ & $13: 24: 37$ & 6 & 1 & $<40$ & very quiet & Disturbance onset & None \\
\hline 12 & $\begin{array}{c}\text { April 18, } \\
2013\end{array}$ & $12: 27: 15$ & 6 & 1 & 100 & very quiet & during the disturbance & $\sim 150 \mathrm{~s}$ \\
\hline 13 & $\begin{array}{c}\text { April 19, } \\
2013\end{array}$ & $11: 29: 24$ & 7 & 1 & $<20$ & very quiet & $\begin{array}{c}\text { quiet background } \\
\text { conditions }\end{array}$ & $\begin{array}{c}\text { before and } \\
\text { after }\end{array}$ \\
\hline 14 & $\begin{array}{c}\text { April 20, } \\
2013\end{array}$ & $12: 07: 02$ & 9 & 2 & 200 & weakly disturbed & during the disturbance & $\begin{array}{l}\text { HF-noise; } \\
25 \mathrm{~s}\end{array}$ \\
\hline 15 & $\begin{array}{c}\text { April 21, } \\
2013\end{array}$ & 11:08:04 & 8 & 1 & $<20$ & very quiet & $\begin{array}{l}\text { quiet background } \\
\text { conditions }\end{array}$ & $\sim 150 \mathrm{~s}$ \\
\hline 16 & $\begin{array}{c}\text { June 13, } \\
2013\end{array}$ & $13: 47: 03$ & 9 & 1 & $<70$ & very quiet & $\begin{array}{c}\text { slight } \\
\text { disturbance }\end{array}$ & $57 \mathrm{~s}$ \\
\hline 17 & $\begin{array}{c}\text { June 14, } \\
2013\end{array}$ & $12: 52: 43$ & 10 & 1 & $<20$ & very quiet & $\begin{array}{l}\text { quiet background } \\
\text { conditions }\end{array}$ & $80 \mathrm{~s}$ \\
\hline 18 & $\begin{array}{c}\text { June 14, } \\
2013\end{array}$ & $14: 29: 04$ & 11 & 1 & $<20$ & very quiet & $\begin{array}{l}\text { quiet background } \\
\text { conditions }\end{array}$ & $65 \mathrm{~s}$ \\
\hline 19 & $\begin{array}{c}\text { June 16, } \\
2013\end{array}$ & $12: 38: 23$ & 8 & 1 & $<20$ & very quiet & $\begin{array}{l}\text { quiet background } \\
\text { conditions }\end{array}$ & $75 \mathrm{~s}$ \\
\hline 20 & $\begin{array}{c}\text { June 17, } \\
2013\end{array}$ & $11: 42: 25$ & 8 & 1 & $<70$ & very quiet & between disturbances & $65 \mathrm{~s}$ \\
\hline 21 & $\begin{array}{c}\text { June } 18, \\
2013\end{array}$ & $12: 22: 08$ & 12 & 1 & 150 & very quiet & Disturbance onset & $70 \mathrm{~s}$ \\
\hline 22 & $\begin{array}{c}\text { April 13, } \\
2014\end{array}$ & $13: 20: 01$ & 19 & 3 & 200 & quiet & during the disturbance & $\begin{array}{l}\text { before and } \\
\text { after }\end{array}$ \\
\hline 23 & $\begin{array}{l}\text { April 14, } \\
2014\end{array}$ & 14:01:09 & 19 & 3 & 10 & very quiet & between disturbances & $60-150 \mathrm{~s}$ \\
\hline 24 & $\begin{array}{c}\text { April 15, } \\
2014\end{array}$ & $13: 05: 31$ & 11 & 2 & 20 & very quiet & $\begin{array}{c}\text { end of } \\
\text { disturbances }\end{array}$ & $\begin{array}{l}\text { long-period } \\
\text { during the day }\end{array}$ \\
\hline 25 & $\begin{array}{c}\text { April 16, } \\
2014\end{array}$ & $12: 09: 29$ & 11 & 1 & 250 & moderately disturbed & $\begin{array}{c}\text { end of } \\
\text { disturbances }\end{array}$ & $\begin{array}{l}\text { before and } \\
\text { after }\end{array}$ \\
\hline 26 & $\begin{array}{c}\text { April 17, } \\
2014\end{array}$ & $12: 49: 01$ & 19 & 2 & 150 & moderately disturbed & Disturbance onset & $\begin{array}{l}\text { before and } \\
\text { after }\end{array}$ \\
\hline 27 & $\begin{array}{c}\text { April 18, } \\
2014\end{array}$ & $11: 51: 51$ & 13 & 1 & 50 & quiet & $\begin{array}{c}\text { end of } \\
\text { disturbances }\end{array}$ & $80 \mathrm{~s}$ \\
\hline 28 & $\begin{array}{c}\text { July } 26 \text {, } \\
2014\end{array}$ & $20: 24: 11$ & 15 & 2 & 30 & very quiet & $\begin{array}{c}\text { end of } \\
\text { disturbances }\end{array}$ & $\begin{array}{c}\text { Long-period } \\
\text { before and } \\
\text { after }\end{array}$ \\
\hline 29 & $\begin{array}{c}\text { July } 27, \\
2014\end{array}$ & $19: 27: 23$ & 10 & 1 & 20 & very quiet & $\begin{array}{l}\text { quiet background } \\
\text { conditions }\end{array}$ & $40-60 \mathrm{~s}$ \\
\hline 30 & $\begin{array}{c}\text { July } 28, \\
2014\end{array}$ & 20:06:07 & 16 & 2 & 350 & quiet & Disturbance onset & $\begin{array}{c}\text { high-latitude } \\
\text { pulsations }\end{array}$ \\
\hline 31 & $\begin{array}{c}\text { July } 29, \\
2014\end{array}$ & 19:08:11 & 11 & 1 & 40 & very quiet & $\begin{array}{c}\text { end of } \\
\text { disturbances }\end{array}$ & $\begin{array}{l}\text { before and } \\
\text { after }\end{array}$ \\
\hline 32 & $\begin{array}{c}\text { July } 30, \\
2014\end{array}$ & 18:09:40 & 8 & 0 & 30 & very quiet & $\begin{array}{l}\text { quiet background } \\
\text { conditions }\end{array}$ & $20-70 \mathrm{~s}$ \\
\hline 33 & $\begin{array}{c}\text { July } 31, \\
2014\end{array}$ & $18: 46: 40$ & 19 & 1 & 200 & very quiet & $\begin{array}{c}\text { end of } \\
\text { disturbances }\end{array}$ & $\begin{array}{l}\text { before and } \\
\text { after }\end{array}$ \\
\hline
\end{tabular}




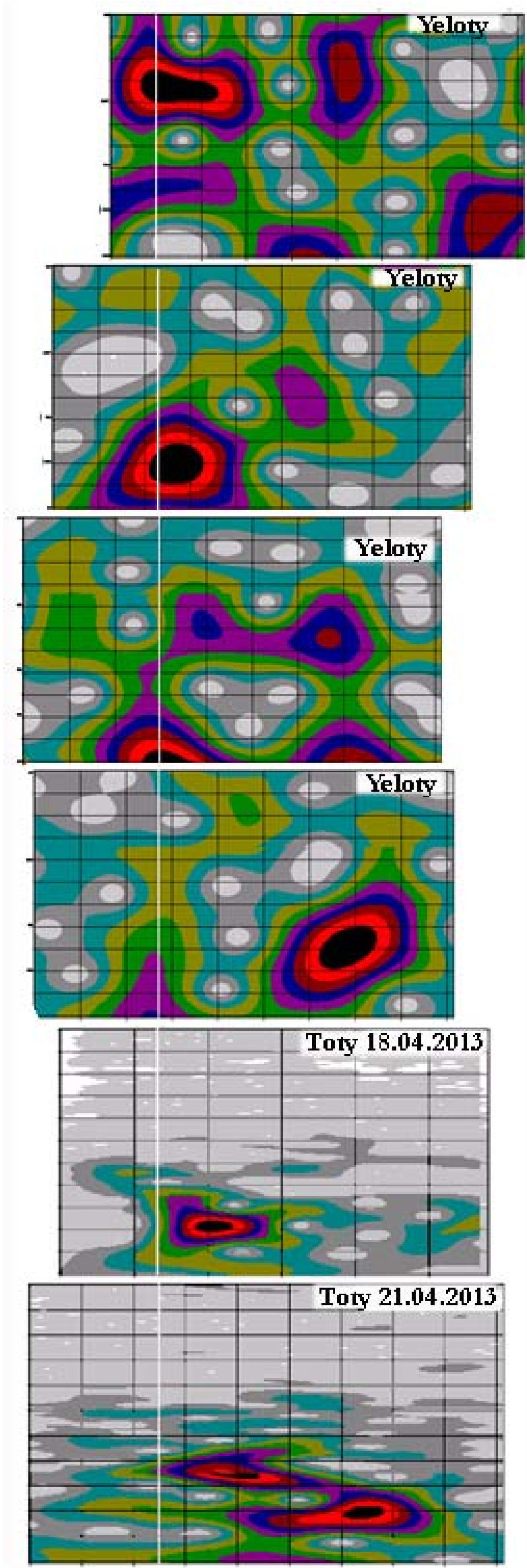

Figure 10. Dynamic spectra of geomagnetic pulsations matched with respect to the instant of ACE start. The vertical white line indicates the start of the PCS's engine running 
In conclusion, we should note the following. If an event of interest occurs during a long period of quiet geomagnetic conditions, particle density in geomagnetic field tubes is insufficient for the development of instabilities in space plasma. In this case, occurrence of geomagnetic variations during PCS's engine running is highly improbable because there is no plasma favoring propagation of disturbances in the magnetospheric resonator and its excitation. During strong magnetic disturbances in the auroral zone in the magnetosphere there exist a wide range of geomagnetic disturbances which hamper registration of wanted signals. Another situation arises when an experiment is conducted after disturbances under quiet background conditions. Geomagnetic field tubes are full of particles of various energies. This allows us to expect positive response of the magnetosphere to engine running.

We should note finally that the number of the experiments we performed is clearly insufficient to draw confident conclusions about the discovered regularities. Especially since the analysis of sources of literature has revealed the lack of studies with such a purpose setting. We think that in future experiments it is necessary to place observational equipment at a calculated point of projection of the field tube on Earth's surface as accurate as possible. In addition, at a short distance from this point, an analogous equipment complex should be situated because the effect can be fairly local.

\section{REFERENCES}

Dmitriev A.N., Robertus Yu.V., Shitov A.V. On the problem of local geomagnetic disturbances during launches of carrier rockets. Fizicheskie problemy ekologii (Ekologicheskaya fizika) [Physical Problems in Ecology (Ecological Physics)]. Moscow: MAKSPress Publ. 2002, no. 8, pp. 32-42. (In Russian).

Fatkullin N.N. Physics of the Ionosphere. Itogi nauki i tekhniki. Geomagtetizm i vysokie sloi atmosfery [Results in Science and Technology. Geomagnetism and high atmospheric layers]. Moscow: VINITI Publ., 1982, vol. 6, 224 p. (In Russian).

Khakhinov V.V., Potekhin A.P., Lebedev V.P., Medvedev A.V., Kushnarev D.S., Shpynev B.G., Zarudnev V.E., Alsatkin S.S., Ratovsky K.G., Podlesny A.V., Bryn'ko I.G. Radiophysical methods of diagnostics of ionospheric disturbances generated by on-board engines of transport spacecraft "Progress": Algorithms, instruments and results. Rossiyskaya nauchnaya konferetsiya "Zondirovanie zemnykh pokrovov radarami s sintezirovannoi aperturoi" [National Scientific Conference Earth Surface Sounding by Radars and Synthetic Aperture]. 2010, pp. 553-569. (In Russian).

Khakhinov V.V., Shpynev B.G., Lebedev V.P., Kushnarev D.S., Alsatkin S.S., Khabituev D.S. Radiosounding of ionospheric disturbances generated by exhaust streams of the transport spacecraft "Progress" engines. PIERS Proc. Moscow, Russia, August 19-23, 2012, pp. 1168-1171.

Lipko Yu.V., Vugmeister B.O., Rakhmatulin R.A. Ionospheric manifestations of geomagnetic pulsations at high latitudes. Geomagnetizm i aeronomiya [Geomagnetism and Aeronomy]. 2001, no. 3, pp. 332-336. (In Russian).

Naumov N., Nikolsky V., Pertsev S., Rudenko V. Military-applied aspects of geophysical research abroad. Zarubezhnoe voennoe obozrenie [Foreign Military Review]. 2014, no. 1, pp. 24-31. (In Russian).

Potekhin A.P., Khakhinov V.V., Medvedev A.V., Kushnarev D.S., Lebedev V.A., Shpynev B.G. Active space experiments with the use of the transport spacecraft "Progress" and Irkutsk IS Radar. PIERS Proc. Moscow, Russia, August 18-21, 2009 , pp. $223-227$.

Rakhmatulin R.A. Subburya $v$ geomagnitnykh pulsatsiyakh. Eksperimenty na meridional'nykh tsepochkahk stantsy Evraziyskogo kontinenta 1973-2003: aftoreferat diss. [Substorm in geomagnetic pulsations. Experiments at meridional chains of Eurasia continent stations 1973-2003. Abstract of dissertation... Dr. Phys. and Math. Sci.]. 2010, 42 c. (In Russian).

Rakhmatulin R.A., Petrovsky M.A. Research into dynamic spectra of high-latitude Pi2 pulsations. Isslelovaniya po geomagnetizmu, aeronomii i fizike Solntsa [Research on Geomagnetism, Aeronomy and Solar Physics]. Moscow: Nauka Publ., 1994, iss. 103, pp. 49-56. (In Russian). 
Rakhmatulin R.A., Pashinin A.Yu. Influence of the ionosphere on the observation of the mid-latitude Pi2 pulsations at the global scale. Chinese J. Space Sci. 2005, vol. 25, no. 5. pp. 447-449.

Smirnova N.V., Kozlov S.I., Kozik E.A. Effect of launches of solid-propellant rockets on the Earth's ionosphere 2. Regions E, E-F. Kosmicheskie issledovaniya [Cosmic Research]. 1995, vol. 33, no. 2, pp. 115-123. (In Russian).

Lebedev V.P., Khakhinov V.V., Gabdullin F.F., Korsun A.G., Tverdokhlebova E.M., Laletina E.A., Manzhelei A.I., Research into characteristics of plasma surroundings of low-orbit spacecraft by radio sounding methods. Kosmonavtika $i$ raketostroenie [Cosmonautics and Rocket Engineering]. 2008, no. 1 (50), pp. 51-60. (In Russian).

URL: http://www.swpc.noaa.gov/ftpmenu/lists/ace.html (accessed March 12, 2016).

URL: http://ipg.geospace.ru/ (accessed March 12, 2016).

URL: http://wdc.kugi.kyoto-u.ac.jp/ae_provisional/index. html (accessed March 12, 2016).

URL: http://ipg.geospace.ru/weekly-geomagnetic-forecast. html (accessed March 12, 2016). 